\title{
Digital Tools Used in Bahasa Indonesia for Non- Native Speakers (BIPA) Online Learning in Canggu Community School
}

\author{
Ni Luh Gede Dian Pondika Cahyaningsih ${ }^{1 *}$
}

\author{
${ }^{1}$ Canggu Community School, \\ *Corresponding author. Email: pondikadian@gmail.com
}

\begin{abstract}
To accommodate online learning for young learners, teachers should find digital tools to create interactive teaching materials and to teach the learners online. Teaching Bahasa Indonesia untuk Penutur Asing (BIPA) or Indonesian as Foreign Language online has been extra work for the teachers since there was a lack of online resources that fit the young learners. Therefore, teachers should make their teaching materials like worksheets, videos, audios, and games to create effective, engaging, and meaningful online learning. This study was conducted to find out the digital tools used by the BIPA teachers in an international school, known as Satuan Pendidikan Kerjasama (SPK) Canggu Community School. This was a qualitative study by utilising interviews, questionnaires, and observation to collect the data. The result of this study showed that the school utilised digital tools included digital tools for video conferencing, tools for live interactive discussion, tools for reading as well as tools for live interactive games. The digital tools to support asynchronous learning included the tools for creating videos, audio, e-books, and language games. Among those tools, some tools could be employed both in synchronous and asynchronous learning. These findings indicated that teachers have various digital tools to facilitate interactive teaching and learning of BIPA.
\end{abstract}

Keywords: Digital tools, Online learning, BIPA, Young learners.

\section{INTRODUCTION}

The pandemic of covid-19 disease has led to the urge for online learning. The disease is linked to the same family of viruses as a severe acute respiratory syndrome and some types of the common cold [15] The virus has widely spread very quickly around the world, it is transmitted through direct contact with respiratory droplets of an infected person through coughing and sneezing. In Indonesia, the first corona-virus disease case was found in West Java on March 2nd, 2020 [15] Since then, actions in preventing the virus spread have been taken. One of the actions was to close public areas where many people gather in the same place. Schools, as one of the public places, should be closed too.

Even though schools were closed, the learning should continue. Schools should plan for the continuity of learning [22]. Natividad [22] also stated that conducting online learning strategies to support social distancing during the pandemic was the first plan. It was followed by assigning reading and exercises for home study. The Indonesian Ministry of Education stated that the education unit in the Covid-19 red zone area should encourage students to learn from home [35]. It was also stated that the home learning program can be conducted in many ways, depending on the students' condition and interest [36]. Students can learn at home through video conferences, home learning materials that were sent home regularly, television, radio, and other digital devices.

Teaching a foreign language requires creativity to attract students' interest. This includes involving stories, dramas, and games in learning the language [1]. During the pandemic, online learning lessons have been a challenge for teachers. According to Okada [24], teachers should be innovative and creative in using digital tools to support the distance learning program. Teachers should find proper digital tools for the students to learn at home [30].

BIPA which stands for Bahasa Indonesia untuk Penutur Asing or the Indonesian language as a Foreign Language has been a subject that is taught in international schools in Indonesia which are known 
nowadays as Satuan Pendidikan Kerjasama or Cooperative Education Unit. Based on the preliminary survey and interview with primary Indonesian language teachers in Canggu Community School in Bali about the need for Indonesian language resources, it was found that there was a lack of digital BIPA teaching and learning resources that are ready to use for the young learners at home during the online learning period. Therefore, this study aims to present digital tools that could be used by the teachers to create language teaching and learning materials to support online learning and to teach interactively with the students during the live online learning.

\section{LITERATURE REVIEW}

\subsection{Teaching a Language to Young Learners}

Scoot and Ytreberg [33] stated that young learners are simply divided into two main groups. The first group is the young learners in the age of five to seven years old, and the second group is at the age of eight to ten years old.

The five to seven years old group has their characteristics of learning a foreign language. According to Scoot and Ytreberg [33], the five to seven years already be able to talk about what they are doing, and what they have done or heard. However, young learners in this group of age have short concentration and focus; therefore, they need short time focus and fun activities [33]. They also enjoy learning through play. Furthermore, Scoot and Ytreberg [33] stated that five to seven years old children sometimes cannot differentiate the fiction and non-fiction. Thus, they can make themselves into the stories, feel something, get moral values related to their life, imagine that they are at the places in the story, and they are easily amazed by the magical thing in the story [30].

The other group of young learners, according to Scoot and Ytreberg [33] is the group age of eight to ten. These children have very decided views of the world. They also can tell the difference between fact and fiction. The young learners in that range of age still ask questions all the time. However, they can decide their learning already. The group of young learners relies on the spoken word as well as the physical world to convey and understand the meaning. They already start to understand an abstract thing, symbols beginning with words and can generalise and systematise words.

A teacher of young learners is expected to have several characteristics that are different from the teachers who teach adult learners. According to Colker [8], a teacher of young learners should show these characteristics showing passion in teaching. Besides that, a young learner teacher should show perseverance to maximise the learning experience for the students. Being flexible to make the learner enjoying the lesson is also suggested [8]. The other important characteristics of a young learner's teacher are respectful, emphatic, and creatively facilitate the learners to the lessons [8].

To teach a foreign language to young learners, teachers should consider some aspects because teaching vocabulary only is not enough [32]. The activities should involve their senses and movement. The teacher is suggested to provide rhymes, songs, and stories. Visuals also play important roles in helping their memory to remembers words and to help them understand sentences [17]

\subsection{BIPA Lesson}

BIPA stands for Bahasa Indonesia untuk Penutur Asing which means the Indonesian language for foreign speakers. Therefore, teaching BIPA is like teaching other foreign languages too. Teaching a language integrating four skills, they are speaking, listening, writing, and reading skills [4]. The Indonesian language has been a subject school in international schools. It means that the Indonesian language has been designated as a subject matter within a school curriculum and thus has certain teaching practices and learning expectations associated with it [19].

\subsection{Synchronous and Asynchronous Online Learning}

Online learning involves the use of technology such as the world wide web, email, chat, texts, audio, and video conferencing about education [3]. In conducting online learning, the teacher should follow these principles: encouraging learners' participation, encouraging learners' cooperation, encouraging active learning, giving feedback, setting the time on task, communicating expectations, respecting different learners' abilities and way of learning [31]. Online 
learning can be delivered in two ways: synchronous and asynchronous modes.

The synchronous mode in online learning happens when the learners collaborating in a virtual classroom at the same time as the teacher [21]. The teachers and the learners meet in a video conferencing, share information, ideas, and learning experiences in a virtual environment [37]. When sharing the ideas in synchronous learning, teachers and learners can apply silent discussion where all participants can see other's thinking, create a visual record of thoughts and ideas, and ensure everyone participating [29]. Synchronous language learning is about the communicative way of language teaching and learning with whiteboards, video chat, or voice chat providing immediate feedback to help the learners improve their language skills [27].

Asynchronous learning is when the learner is supported with media such as e-mail and discussion board when cannot be online at the same time [12]. Asynchronous learning involves self-paced activities that the learners take when it's convenient for them from anywhere [16]. Moreover, Kokoulina [16] mentioned digital formats that can be used for conducting asynchronous learning. They are LMS or Learning Management System, discussion through emails, training videos, and other digital reading resources [16].

\subsection{Digital Tools}

The rapid change of technology in society as well as in education at schools has brought us to an era with various digital tools. Digital tools emphasise the proceeding learning activity of the learners through computers, laptops, hand phones, tablets, or notebooks [13]. Digital tools also offer opportunities to promoting creativity by expanding the possibilities of students to learn in many ways[18].

The use of digital tools is expected to enrich and facilitate the learning experience for young learners [28]. There are a lot of digital tools that can support students' learning. Not all those tools are free to use. Some tools offer free to use but are limited. In choosing the digital tools to support any activity, Sipes [34] suggested finding a balance between affordability and performance. In Indonesia, the Ministry of Education has enhanced the quality of online learning for students by accommodating the teachers with free usage of some digital tools [39].

\section{METHOD}

This research is a descriptive qualitative approach. This study involved the Bahasa Indonesia as foreign language teachers in Canggu Community School, Bali. To collect data, this study employed interviews, questionnaires, and observation. The questionnaire and interview were conducted to get data about the digital tools utilized by the teachers to teach synchronously and asynchronously. The observation was conducted to gather information about how digital tools were employed to support online learning. The data was analysed by highlighting the main themes and relevant sub-themes regarding the digital tools for teaching interactively.

\section{RESULT AND DISCUSSION}

This study was aimed to present the use of various digital tools in designing the home learning materials and supporting the primary school students in Canggu Community School to learn the Indonesian language as a foreign language.

\subsection{Indonesian Language Online Learning at Canggu Community School (CCS) for Primary Students}

In Indonesian language lessons at Canggu Community School for primary students, there were six activities given to them. It involved the four skills of language learning (speaking, listening, reading, and writing) [4] and was added by grammar and games. Those activities were: Ayo Dengarkanlah (Listening activity), Ayo Bicara (Speaking activity), Ayo Membaca (Reading activity), Ayo Menulis (Writing activity), Tata Bahasa (grammar), and Ayo Bermain (Language game activities).

The teaching and learning materials were prepared both for synchronous and asynchronous learning. They were sent weekly to Google Classroom or e-mail on Mondays. Students who were in the same time zone, as well as with one- or two-hours differences, joining the live online lessons Meanwhile, the students who were in more than 3 hours - difference provided asynchronous learning materials. Therefore, the materials should be able to be accessed anytime.

Children in the first and second grades of primary school, still need parental supervision in learning because they have not been able to study independently [23]. Based on observations, the parents of younger learners from the age of five to seven years 
old in CCS helped the children to operate the devices at their house. They also help their children to check the weekly plan online activities from the teachers that sent to their school e-mail. When the younger learners had live online lessons, a parent or other adult person in their house would accompany them to help them operating the digital tools based on the teacher's instructions. For some parents who need the printed resources, they could contact the school and make an appointment to take the resources at school.

The older young learners from the age of eight to ten years old were more independent. They could check their e-mail as well as google classroom to find out the learning resources and assignments sent by the teachers. They learned fast in using the digital tools that are used in online learning. However, clear and simple instructions from the teacher were needed to make it understandable for them to use the tools when doing the online learning [16].

\subsection{Digital Tools of Synchronous Online Learning for Young Learner in CCS}

To facilitate the learners and the teachers to interact with each other during online lessons, there were nine tools applied. Those tools were:

\subsubsection{Video Conferencing with Google Meet Nicknames}

Video conferencing is an example of the synchronous model in online learning [37]. The teachers and students at CCS used Google Meet for the live online lessons. This app could be accessed at https://meet.google.com or by installing it on devices. To join the google meet, both teachers and students should enter a code. The common code for a google meet is usually the combination of ten letters. To make it easier for the young learners, every teacher set nicknames which much easier for them to remember. Besides that, setting a nickname for a google name also can prevent students from entering the google meet before the teachers have joined [5]. During the live video conferencing, the learners talked about what they are doing, and what they have done or heard [33]. All of the teachers in this study used google meet with nicknames in their online teaching and learning.

\subsubsection{Live Interactive Language Games with} Quizlet Live, Kahoot, Scribble.io and Quizizz.

Distance learning could be comfortable when the students feel fun and comfort emotionally [40]. Moreover, the majority of learners agreed that effective distance learning could happen when they are happy, enjoy and feel fun while learning [23]. Young learners can be pleasured and fun when they play games [25].

Four tools were applied to have interactive language games for the young learners in CCS. As synchronous online learning tools, they allowed the learners to get immediate feedback to help the learners improve their grammar, vocabulary knowledge, reading, and writing skills [27]. Those tools were Quizlet Live, Kahoot, Scribbl.io, and Quizizz.

Quizlet Live was a tool where the teacher can make a set of vocabulary both in the target language and the first language. The teachers made a set of word lists, both the terms and definitions. After that, the teachers saved it. The saved set of words can be used as many times as needed. Based on the result of the questionnaire and interview, this tool was frequently utilised by $71.4 \%$ of the Indonesian language teachers in CCS, $14.1 \%$ of the teachers occasionally using this tool, and $14.1 \%$ rarely using this tool. Quizlet was used at the beginning of the lesson to introduce vocabulary related to the topic of learning. All the terms and definitions in that set were formed into digital flashcards. Those flashcards were used for introducing new vocabulary before teaching the main lesson. Pictures were added in the flashcard since visuals also play important roles in helping their memory to remembers words and to help them understand sentences [17]. All Indonesian teachers also used this tool at the end of the lesson to test the learners' understanding and memorize the new vocabulary that they had just learned. The teacher chose a set of words, clicked "live", chose options of how the game would be expected- team, individual, term to definition, or definition to the term. After that, the link www.quizlet.live and a code that consists of six numbers were sent to the students. Students could join using their names or nicknames, with or without signing in the Quizlet. The questions were seen in the students' own devices. The signs of progress were monitored by the teacher.

Kahoot is another tool to learn while playing. In CCS, Kahoot was frequently employed $42.9 \%$ of Indonesian language teachers, $28.6 \%$ of the teachers occasionally used it, and the other $28.6 \%$ of them rarely utilised it in their online lessons. This tool was employed to teach students new vocabulary as well as to review the vocabulary that the students had learnt. 
In live online learning, Kahoot required the teacher to screen-sharing to let the students see the questions as well as the options. Besides that, it showed the scoreboard during and at the end of the game. It showed competition yet it can motivate them in learning [7]

Quizizz was also a tool used in Bahasa Indonesia online learning in CCS. This tool was used by the teacher to do assessments in a fun way. Compared with Quizlet and Kahoot, Quizizz can provide longer text in a question box. Quizizz was frequently used by $14.3 \%$ of the Indonesian language learners, occasionally used by $42.9 \%$ of them, and $57.1 \%$ of the teachers rarely employed this tool in their BIPA online learning and teaching.

Scribbl.io is a tool where the participants of the game can guess a word from the pictures drawn by another participant. Firstly, the teacher made a set of words. And then, a link for joining the activity was shared with the learners to be participants of the game. All participants got chances to choose a word and draw pictures as clues for other participants to guess the word or phrase. This tool was employed frequently by $28.6 \%$ of the teachers, $42.9 \%$ of them occasionally flashcards [32]. Quizlet became the tool that was most frequently used by the teachers in this study because it was much easier for the teachers and learners to see the questions and multiple choices on the learner's device rather than looking at the teacher's screen sharing during live online learning. It also gives the learners a refresher from focusing on the teacher's sharing screen to their own. Besides that, the vocabulary could be accessed and learned anytime by the learners.

\subsubsection{Live Discussion with Google Jamboard, Padlet, and MindMeister}

Synchronous learning in CCS encouraged the teachers and students to share information, ideas, and learning experiences virtually [37]. Discussion during live online learning was not only spoken but also written. The silent discussion was used in the online learning to let the students exploring a topic in-depth, give them opportunities to see other's thinking, create a visual record of students' thoughts and ideas, and ensure everyone participating since it is not monopolised by a few voices [29]. Therefore, to make a focus yet interactive discussions, the teachers employed digital tools to facilitate the discussions.

Table 1. The Frequency of Using Digital Tools for Live Interactive Games and Quizzes in BIPA Online Learning

\begin{tabular}{lccccc}
\hline Digital Tools & $\begin{array}{c}\text { Frequently } \\
(\%)\end{array}$ & $\begin{array}{c}\text { Occasionally } \\
(\%)\end{array}$ & $\begin{array}{c}\text { Rarely } \\
(\%)\end{array}$ & $\begin{array}{c}\text { Never } \\
(\%)\end{array}$ & $\begin{array}{c}\text { Mean } \\
\text { score }\end{array}$ \\
\hline Quizlet & 71.4 & 14.3 & 14.3 & 0.00 & 89.3 \\
\hline Kahoot & 57.1 & 28.6 & 14.3 & 0.00 & 85.7 \\
\hline Quizizz & 14.3 & 42.9 & 57.1 & 0.00 & 75.0 \\
\hline Scribble.io & 28.6 & 42.9 & 28.6 & 0.00 & 78.6 \\
\hline
\end{tabular}

used it, and $28.6 \%$ rarely employed it.

Table 1 showed that Quizlet was the digital tool that was frequently used by the Indonesian language teachers in teaching BIPA online. Kahoot and Scibble.io were the next tools that were also frequently used by the teachers. Quizizz became the least frequent tool used by the teachers. In learning a foreign language, vocabulary knowledge is assumed to be a critical tool for the learners because a limited vocabulary in a foreign language learning can inhibit successful communication [2] Those tools were utilised to review vocabulary and to help them memorise words through pictures and digital
The first tool that was used by the teachers to conduct a live silent discussion was Google Jamboard. This tool allowed the teachers to add pictures, write texts and post-it notes, as well as draw doodles. Once it was shared with the students, they could view or even edit it. When it was shared to be edited, students could write on it, draw lines and give annotation, write post-it notes, etc. The teachers put a picture related to the topic, and then students wrote post-it notes on it telling what they know about the pictures. Everybody, who can access the link of the Jamboard, could view the written discussion. This tool was frequently employed by $57.1 \%$ of the teachers. Meanwhile, only 
$28.6 \%$ of the teachers occasionally used this tool, and the rest $14.3 \%$ rarely used it.

The next tool for the online silent discussion was Padlet. Padlet was used by the teachers to let the students write their thoughts supported with doodles, pictures, and videos. Once the link to the padlet was shared with students, they were able to write their thoughts based on the topic that they were learning. They also could put pictures and videos to support their thoughts or opinions. This tool was frequently used by $14.3 \%$ of the teachers, occasionally used by 42.9 of them, $28.6 \%$ rarely used it, and $14.3 \%$ never used it.

The last tool used by the teachers at this school to teach BIPA was MindMeister. This tool allowed the teachers and students to make a mind map. The mind map is a technique to uncover someone's thoughts which consists of a centre of discussion, branches that are connected to the centre and each other [10]. This tool was used occasionally by $14.3 \%$ of the teachers, the other $57.1 \%$ of them rarely used mind-meister, and the rest $42.9 \%$ never used it in their online learning. the jamboard so that both teachers and students could write, annotate and add pictures on it.

\subsubsection{Live reading e-book resources from Literacy.org and reader.letsreadasia.org}

After delivering the main lessons, the teachers usually read storybooks for the students. The young learners were interested in the stories told $\mathrm{b}$ the teachers since the stories could make them feel happy, sad, curious, and excited [30]. The e-books in literacy.org and reader.letsreadasia.org were free to be accessed by any users. The affordability of those two tools was one of the reasons why the teachers choose them [34]. The availability of Indonesian children's books and stories about Indonesia was the other reason why the teachers chose these tools. Especially in literacy.org, many children storybooks showed Indonesian cultures. Those could make the young learners imagined that they were in Indonesia and felt the experiences of Indonesian cultures, as stated by Riedel about putting the children into the experiences in the storybooks that they hear or

Table 2. The Frequency of Using Digital Tools for Live Interactive Silent Discussion in BIPA Online Learning

\begin{tabular}{lccccc}
\hline Digital Tools & $\begin{array}{c}\text { Frequently } \\
(\%)\end{array}$ & $\begin{array}{c}\text { Occasionally } \\
(\%)\end{array}$ & $\begin{array}{c}\text { Rarely } \\
(\%)\end{array}$ & $\begin{array}{c}\text { Never } \\
(\%)\end{array}$ & $\begin{array}{c}\text { Mean } \\
\text { Score }\end{array}$ \\
\hline $\begin{array}{l}\text { Google } \\
\text { Jamboard }\end{array}$ & 57.1 & 28.6 & 14.3 & 0.00 & 85.7 \\
\hline Padlet & 14.3 & 42.9 & 28.6 & 14.3 & 64.3 \\
\hline MindMeister & 0.00 & 14.3 & 57.1 & 42.9 & 50.0 \\
\hline
\end{tabular}

read [30].

Table 2 showed that Google Jamboard was the tool that was frequently used by the teachers in this study to conduct a live silent discussion with the students during the online learning. Google Jamboard is easy to be used by teachers and young learners since it has simple and visible buttons of pen, erasers, select, colourful sticky notes, shapes, text box, and laser on the left side. Meanwhile, the other tools, like Padlet and Mindmeister, the buttons of the tools are hidden. Jamboard also has colourful digital post-it notes which looked interesting for young learners. Besides, the teachers could use the worksheets as a background of
The learners were allowed to choose the books to be read. According to Wilhelm [40], reading for pleasure ensures the learners choose whatever they want to read since it could promote cognitive progress and social possibility.

\subsection{Digital Tools of Asynchronous Online Learning for Young Learners in CCS}

The teachers in this study also prepared teaching and learning materials for asynchronous mode. They combined various digital tools to make videos, audio, 
digital worksheets, e-books, comics, and many more based on the learners' needs. As the teachers for young learners, they were flexible to the learners' conditions and creatively facilitated the learners to the lessons based on the learners' needs [8].

\subsubsection{Learning Management System Tools: Google Classroom and Wabisabi}

As stated by Kokoulina [16], applying a learning management system is the best way to conduct asynchronous learning. The teachers at CCS in this study used Google Classroom to post the learning resources for grades 4,5 and 6 . The teachers sent the learning materials, assigning works, discussing the topic, and grading students' works. Meanwhile, for the younger learners, the teachers sent the weekly plan and resources through email and using Wabisabi to post activities, posting the students' works, grading, and giving feedback. The learning materials posted in those LSM were in the forms of worksheets, videos, audio, links to e-books to read and links to the language games. To prepare those learning materials, the teachers utilised various tools.

\subsubsection{Digital Tools for Creating Listening and Speaking Activity}

The material should help the learners to feel at ease when learning [11]. In creating the teaching materials, that were sent to the young learners, the teachers prepared videos and audios for listening activities. Videos and audio could be the most convenient resources in asynchronous learning [16]. They were used for the learners to practice their listening comprehension and speaking. The audios and videos were created by using these tools:

\subsubsection{Online-voice-recorder.com}

By using this tool, the teachers could not only record voices but also trim audios, join more than one audio, change the volume and speed, reverse audio and set audio with an equalizer. Besides, using this tool also allowed teachers to trim, crop, rotate videos based on the user's need.

\subsubsection{Pixton.com}

Pixton allowed the teachers to make comics with various characters, facial expressions, acts, and backgrounds. The comic was downloaded and then edited together with the audio. Therefore, the young learners would not only read the comic but also listen to the audio that was already put in it.

\subsubsection{Canva Pro Education}

Canva was like an all-in-one tool that let the teachers edit worksheets for listening activities, transform comics into videos with sound, and also create videos with interesting pictures. In the pro version, all files could be downloaded in the form of pdf, png., mp4., ppt., jpg.,giv., and svg. For listening and speaking activities, the videos were downloaded in the mp4 format.

\subsubsection{Edpuzzle}

Edpuzzle lets its users answer interactive questions while watching a video. This tool was employed by the teachers to ask questions related to the videos sent to the learners. The video could be uploaded by the teacher or taken from YouTube and other video resources. Firstly, the learners were invited to join a class on Edpuzzle. Next, they would get an assignment from their teacher to watch a video and answer questions that appeared when they watching it. After answering all questions, students would turn them in. The teachers could check the answers and grade them.

\subsubsection{Wabisabi}

This tool was employed to let the learners post their videos or audios when they practice a conversation, do monologues, or sing Bahasa Indonesia songs. The teachers could post learning materials as well as check the learners' posts. In wabisabi, the teachers were also able to grade the learners' performance. To join the teacher's wabisabi class, the learners should join through a code sent to them.

\subsubsection{Google Slide}

The listening worksheets were usually sent digitally in the form of pdf. Google slide was used by the teachers to make the pdf file consist of links to the audio or video related to the lesson. Therefore, the pdf worksheets were the only file sent to the learners since they can click on the pictures that connected to the videos or audios.

\subsubsection{Bitly}

The worksheets were sometimes printed and distributed to the parents of the learners who took them at school weekly. In that case, short links should be generated to ease the parents find the audio or video files that could support the learners' listening and speaking skills. Bitly.com was the tool employed by the teachers to make these short links and barcodes. 


\subsubsection{Digital Tools for Reading and Writing Activities}

It was mentioned that digital reading resources could be utilised in asynchronous learning [42]. Digital reading websites are also tools to support asynchronous learning [42]. In the reading and writing activities of the Bahasa Indonesia lesson at CCS, the tools that were used by teachers as follow:

\subsubsection{Literacy.org and reader.letsreadasia.org}

Since these tools were able to be accessed online, so the teachers utilised them to support the learners' interests in reading. The teachers put the links of some stories that could be read anytime and anywhere by the learners.

\subsubsection{Canva Pro Education}

In preparing the teaching and learning materials to support the young learners' online learning, the teachers in this study used Canva Pro Education to design and create the workbook and coursebook that were internally used by the students of Canggu Community School. This tool allowed the teachers to use pictures and other decorative elements to support the content of the materials. The learning and teaching materials that were downloaded for supporting the learners were usually in pdf or ppt files. In writing, the learners in grades 5 and 6 utilised Canva to write functional texts like brochures, advertisements, letters, recipes, and many more.

\subsubsection{Digital Tools for Learning the Vocabulary and Grammar through Games}

Since young learners have short concentration and focus, they need short time focus and fun activities [33]. Language games through some digital platforms were utilised by the teachers to review vocabulary and grammar. In asynchronous BIPA learning at CCS, the digital tools for playing the language games were as follows.

\subsubsection{Kahoot Challenge}

Kahoot was not only employed for synchronous learning. This tool has a mode named Kahoot Challenge. By accessing create.kahoot.it, the teacher made a quiz, true or false, word puzzle and other forms of activity. After saving the quiz, the teacher chose the "assign" mode. It let the teacher get a link to be shared with the learners who were doing the asynchronous learning. This Kahoot Challenge could be done by anyone who got the link within the allotted time.

\subsubsection{WordWall}

This tool consists of various activities. In the free mode, word wall let its users play a set of words through games like match up, open the box, quiz, find the match, random wheel, unjumble, matching pairs, maze chase, missing words, group sort, gameshow quiz, random cards, word search, anagram, labelled diagram, true-false, image quiz and flip tiles. There are many more activities in the pro mode.

The teachers in this study used WordWall to support the learners to be able to learn anytime and anywhere [16]. The links to the WordWall game were sent to the learners. The learners could write their names on the leaderboard so that the teacher could see how was their progress.

\subsubsection{Quizlet: Match and Gravity}

Quizlet also provided asynchronous activity namely Match and Gravity. In Match mode, the users can match the terms and definitions. Meanwhile, in Gravity mode, the users should type either terms or conditions correctly to be able to 'avoid' the fallen asteroids. The teachers in this study shared the link of Match and Gravity mode to the learners as one of many options for fun and meaningful language learning that could be done asynchronously.

\subsubsection{Thewordsearch.com}

Even though word searchers look simple, they can put children in front of a wider range of vocabulary, they are a quick-fire way to evolve children's grasp of the language (twinkle.co.id). This tool helped the teachers to create an easy and quick word search game. The site could be found at www.thewordsearch.com. The title, description, and word list were put in the provided boxes. After submitting the word list, it would be automatically generated into a set of word search games. The teachers in this study would put the word search into the worksheets to be printed or formed into pdf. Alternatively, a link to the word search could be shared with the learners so that they could play it on their computers or tablets.

\section{CONCLUSION}

The lack of BIPA resources for young learners to support online learning was overcome by using the combination of digital tools. The digital tools were utilised both for synchronous and asynchronous learning. The digital tools for synchronous learning included digital tools for video conferencing, tools for 
live interactive discussion, tools for reading as well as tools for a live interactive game. The digital tools to support asynchronous learning included the tools for creating videos, audio, e-books, and language games. Among those tools, some tools could be employed both in synchronous and asynchronous learning. Those tools were Quizlet, Kahoot, Canva, Google Workspace for Education (Google Slide, Docs, Jamboard, etc.).

\section{REFERENCES}

[1] S. Akcan, Grades 2 and 3: Connecting Grammar to Meaning for Children Learning English as a Foreign Language. YC Young Children, vol. 69, 2014, pp. 22-27.

[2] M. Alqahtani, The Importance of Vocabulary in Language Learning and How to Be Taught. International Journal of Teaching and Education, vol. 3(3), 2015. DOI: 10.20472/TE.2015.3.3.002

[3] S. Arora, S. Sakshi. (2019, May). Online Learning. Retrieved from https://www.researchgate.net/publication/3328333 60_Online_Learning

[4] H. D. Brown, Teaching by Principles: An Interactive Approach to Language Pedagogy, White Plains, New York, Longman.

[5] R. Byrne, Richard, How to Use Nicknames in Google Meet - And Why You Should Try It, Retrieved from https://www.freetech4teachers.com/2020/08/howto-use-nicknames-in-google-meet- and.html

[6] J. Cady, T. Hodges, C. L. Brown, C, Supporting language learners. Teaching Children Mathematics, vol. 16, 2010, pp. 476-483.

[7] C. Chitwood, (2017, October 24). Let the Game Begin: Using Competition to Motivate the Students and Staff. Retrieved from https://www.nassp.org/2017/10/24/let-the-gamesbegin-using-competition-to- motivate-the-studentsand-staff/

[8] Colker, L, Twelve Characteristics of Effective Early Childhood Teachers, in: Proceedings of YC Young Children, vol. 63, 2008, pp. 68-73.

[9] J. Eccles, The Development of Children Ages 6 to 14. In: Proceedings of The Future of Children, vol. 9, 1999, pp. 30-44. DOI: doi:10.2307/1602703
[10] Aliye. Erdem, Mind Maps as A Life-long Learning Tool. Universal Journal of Educational Research vol. 5, 2017, pp. 1-7, DOI:10.13189/ujer.2017.051301

[11] Y. M. Harsono, Developing Learning Materials for Spesific Purposes, in: Proceedings of TEFLIN Teaching as A Foreign Language in Indonesia. 2007.

[12] S. Hrastinki, (2008, November 17). Asynchronous and Synchronous E-Learning. Retrieved from https://er.educause.edu/articles/2008/11/asynchron ous-and- synchronous-eLearning

[13] D. T. Keane, Leading with Technology. The Australian Educational Leader, vol. 34, 2012, pp. 44.

[14] P. Kerr, (2020, June 24), Making asynchronous speaking practice meaningful. Retrieved from: https://www.cambridge.org/elt/blog/2020/06/24/ma king- asynchronous-speaking-practice-meaningful/

[15] Kompas.com. (2020, March 3), Fakta Lengkap Kasus Pertama Virus Korona di Indonesia.Retrieved from https://nasional.kompas.com/read/2020/03/03/0631 4981/fakta-lengkap-kasus- pertama-virus-coronadi-indonesia?page $=$ all

[16] o. Kokoulina (2020, March 6), Asynchronous Learning Simply Put: Definition, Benefits, and Tools. Retrieved from https://www.ispringsolutions.com/blog/asynchrono us-learning

[17] H. Kouyoumdjian (2012, July 20), Learning Through Visual: Visual Imagery in the Classroom. Retrieved from https://www.psychologytoday.com/us/blog/getpsyched/201207/learning-through-visuals

[18] P. Kumar, V. Raja, Digital Tools in Learning. $2019 . \quad$ Retrieved from https://www.researchgate.net/publication/3315888 $\underline{42}$

[19] D. Larsen-Freeman, Language Moves: The Place of "Foreign" Languages in Classroom Teaching and Learning, in: Proceedings of Review of Research in Education, vol. 32, 2008, pp. 147-186. DOI: https://doi.org/10.3102/0091732X07309426

[20] Lin, H. Ming Hun, A Study of the Effect of Digital Learning on Learning Motivation and Learning 
Outcome, in: Proceedings of EURASIA Journal of Mathematics Science and Technology Education. 2017. DOI: 10.12973/eurasia.2017.00744a

[21] J. Mahiri, Digital Tools in Urban Schools: Mediating a Remix of Learning. ANN ARBOR: University of Michigan Press. 2011. DOI: $10.2307 /$ j.ctv65swfn

[22] Ed. Natividad, (2020, May 26). Education Must Continue Despite of Pandemic. Retrieved from http://tarlakenyo.com/education-must-continuedespite-pandemic/

[23] R. Novianti, M. Garzia, Parental Engagement in Children's Online Learning During Covid-19 Pandemic. Journal of Teaching and Learning in Primary Education, Vol.3, 2020. DOI http://dx.doi.org/10.33578/jtlee.v3i2.7845

[24] A. Okada, (2020, April 23). Distance Education: Do Students Believe It Should be Fun? Retrieved from

https://www.open.edu/openlearn/educationdevelopment/learning/distance-education-dostudents-believe-it-should-be-fun

[25] A. Pachtman, K. Wilson, What Do the Kids Think? The Reading Teacher, vol. 59, 2006, pp 680-684

[26] Parenting Research. (2020, December 30). The Revealing Reason Why Kids Love Video Games. Retrieved from https://thoughtfulparent.com/whyare-video-games- addicting.html

[27] A. Perveen, Synchronous and Asynchronous ELanguage Learning: A Case Study of Virtual University of Pakistan, in: Proceedings of Open Praxis, vol. 8, 2016, pp. 21-39.

[28] A. Presser, D. Kamdar, R. Vidiksis, M. Goldstein, X. Dominguez, J Orr, GROWING PLANTS And MINDS: Using digital tools to support preschool science learning, in: Proceedings of Science and Children, vol. 55, 2017, pp. 41-47.

[29] D. Ricket, Silent Discussions in the Classroom. 2021. Retrieved from https://davidrickert.com/silent-discussions-in-theclassroom/

[30] R. Riedel, N. Kari, Why Kids Say They Love Fairy Tale. 2021. Retrieved from https://www.readbrightly.com/why-kids-love-fairytales/
[31] C. Robinson, Technology tools for paperless homework, in: Proceedings of Science Scope, vol. 41, 2017, pp. 18-21.

[32] M. N. O. Sadiku, P. O. Adebo, S. M. Musa, Online Teaching and Learning, in: Proceedings of International Journals of Advanced Research in Computer Science and Software Engineering, vol. 8. 2018. Retrieved from https://www.researchgate.net/publication/32482109 0

[33] W. A. Scott, L. H. Ytreberg, Teaching English to Children, Harlow, Pearson Education Limited, 2004.

[34] J. Sipes, Digital Tools for Design/Build. Landscape Architecture, in: Proceedings of JSTOR, vol. 94 2004, pp. 86-94.

[35] Surat Edaran Mendikbud No 4 Tahun 2020 Tentang Pelaksanaan Kebijakan Pendidikan Dalam Masa Darurat Penyebaran Corona Virus Disease Covid-19. (2020, March 24). Retrieved from : https://pusdiklat.kemdikbud.go.id/suratedaran- mendikbud-no-4-tahun-2020-tentangpelaksanaan-kebijakan-pendidikan-dalam- masadarurat-penyebaran-corona-virus-disease-covid-19/

[36] Surat Edaran Nomor 3 Tahun 2020 Tentang Pencegahan COVID-19 pada Satuan Pendidikan. (2020, March10). Retrieved from : ]https://www.kemdikbud.go.id/main/blog/2020/03/ surat-edaran-pencegahan- covid19-pada-satuanpendidikan

[37] Synchronous Learning Tools, 2021. Retrieved from

https://carleton.ca/tls/teachingresources/teachingwith-technology/synchronous-learning-tools/

[38] The Benefits of Word Search Games for Kids, $2019 . \quad$ Retrieved from https://www.twinkl.co.id/blog/the-benefits-ofword-search-games-for-kids

[39] Tingkatkan Akses Layanan Pembelajaran, Kemendikbud Luncurkan Akun Pembelajaran:belajar.id. (2020,December 11). Retrieved from: https://www.kemdikbud.go.id/main/blog/2020/12/ti ngkatkan-akses-layanan-pembelajarankemendikbud-luncurkan-akun-pembelajaranbelajarid 
[40] W. Judy, The Neuroscience of Joyful Education, Engaging the Whole Child, 2017. Retrieved from https://www.psychologytoday.com/files/attachment s/4141/the-neuroscience-joyful- education-judywillis-md.pdf

[41] Y. Yang, L. Cornelius, Preparing Instructors for Quality Online Instruction. Journal of Distance Learning Administration, vol. 8, 2005. Retrieved from https://www.westga.edu/ distance/ojdla/spring $81 / \mathrm{y}$ ang81.htm 